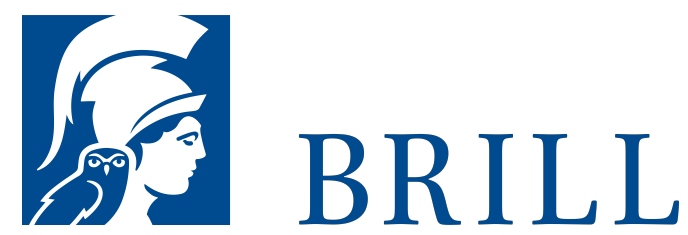

\title{
Vision und Magie
}

Religiöses Erleben im Mittelalter

Author: Peter Dinzelbacher

In der religiösen Kultur des Mittelalters spielten Visionen eine viel größere Rolle als in allen früheren oder folgenden Epochen. Sie traten in den verschiedensten Lebensbereichen auf, darunter bisher noch kaum beachtete.

Ein Magier schafft sich seine eigene Welt aus visionär eingegebenen Ritualen, Zauberer werden visionär entlarvt, das Wesen der Nekromantie basiert auf Totenerscheinungen, die Gesichter der Hexen und der Besessenen zeichnen eine Gegenwelt voller Dämonen. Um diese Phänomene zu verstehen, ist ein psychologischer Zugang unabdingbar: Inwieweit lassen sich auf die mittelalterlichen Visionen moderne Studien zur Halluzination anwenden? Sind Visionen generell als Krankheitssymptome zu verstehen und differieren mittelalterliche und moderne Psychen? Wie wurden Visionäre im Urteil der Zeitgenossen rezipiert? Ein Ausblick auf Vision und Visionsliteratur in der Neuzeit beschließt den Band, wobei auch die konträre Entwicklung im Katholizismus und Protestantismus thematisiert wird.

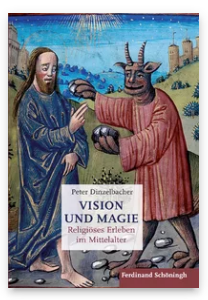

Published: o1 Jan 2019

Pages: VI +221

Seiten, $10 \mathrm{~s} / \mathrm{w}$ und 13 farb. Abb.

Subjects:

General, Theology and World Christianity Publisher: Brill | Schöningh E-Book (PDF) ISBN: 978-3657-78732-6 Price:

Hardback ISBN: 978-3506-78732-3 Price: 
Peter Dinzelbacher ist ein österreichischer Mediävist und Professor für Sozial- und Mentalitätsgeschichte am Institut für Wirtschafts- und Sozialgeschichte der Universität Wien.

Please send your order to: Brockhaus/Commission

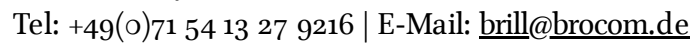

For questions please contact: Brill Deutschland GmbH Wollmarktstraße 115 | 33098 Paderborn | Germany

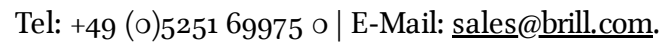

